\author{
VIKTORIA SERZHANOVA \\ ORCID: 0000-0002-8824-7192 \\ Uniwersytet Rzeszowski
}

\title{
KONSTYTUCYJNE PODSTAWY ORGANIZACJI I FUNKCJONOWANIA SĄDOWNICTWA W FINLANDII
}

\begin{abstract}
Abstrakt: Współcześnie niezależność sądów i niezawisłość sędziów stanowią podstawowe atrybuty wymiaru sprawiedliwości w demokratycznym państwie prawnym. Na gruncie systemu konstytucyjnego Finlandii ustawa zasadnicza z 1999 roku tworzy dualistyczny ustrój sądownictwa, składający się z sądów powszechnych i administracyjnych. Celem niniejszego opracowania jest poddanie przepisów finlandzkiej ustawy zasadniczej, będącej konstytucyjną podstawą organizacji i funkcjonowania sądownictwa powszechnego w Finlandii, analizie prawnej, która pozwoli na wysunięcie wniosku, że sądy działają jako obiektywne i bezstronne organy wydające wyroki stosunkowo jednolite w podobnych sprawach. W swoich orzeczeniach są one niezawisłe i nie podlegają kontroli państwa w zakresie orzekania. Orzeczenia sądowe są ostatecznym środkiem gwarantującym stronom poszanowanie ich praw w stosunkach z państwem.
\end{abstract}

Słowa kluczowe: niezależne sądy, niezawiśli sędziowie, ustawa zasadnicza Finlandii z 1999 roku

\section{WPROWADZENIE}

Współcześnie niezależność sądów i niezawisłość sędziów to fundamentalne atrybuty wymiaru sprawiedliwości w demokratycznym państwie prawnym. Prawo do niezależnego i bezstronnego sądownictwa jest uznawane za element szerokiej gwarancji prawa do rzetelnego procesu, szczególnie akcentowanego w międzynarodowych i regionalnych traktatach dotyczących praw człowieka, i wiąże się ono $\mathrm{z}$ autonomią instytucjonalną sądów oraz szczególnym statusem sędziów. Owe atrybuty niezależnego sądownictwa zakładają jego samoregulację i samorządność, co obejmuje między innymi organizację pracy sądów i działalności korpusu zawodowego sędziów ${ }^{1}$.

${ }^{1}$ Por. G. Ambrasaite-Balynienè, Comparative Analysis on the High Councils for Judiciary in the EU Member States and Judicial Immunity, European Commission / ENPI, październik 2015, s. 1. 
Na gruncie systemu konstytucyjnego Finlandii ustawa zasadnicza z 1999 roku $^{2}$ tworzy dualistyczny system sądownictwa, charakterystyczny dla tradycji wschodnio-nordyckiej ${ }^{3}$ : sądów powszechnych oraz odrębnych od nich sądów administracyjnych ${ }^{4}$. Na sądach powszechnych spoczywa główny ciężar rozstrzygania konfliktów wynikających ze stosunków prawnych w zakresie prawa cywilnego i karnego, w zakresie zaś prawa administracyjnego właściwe są sądy administracyjne.

Celem niniejszego opracowania jest poddanie analizie prawnej postanowień finlandzkiej ustawy zasadniczej, stanowiących konstytucyjnoprawne podstawy organizacji i funkcjonowania sądownictwa w Finlandii, będącego najistotniejszym elementem konstytutywnym demokratycznego państwa prawa oraz najważniejszym ogniwem i filarem wymiaru sprawiedliwości. Ważne w tym kontekście jest zbadanie i ocena tego, czy zespół naczelnych zasad konstytucyjnych oraz innych postanowień ustawy zasadniczej, na których oparto system sądów i ich działalność — jako najważniejszego elementu wymiaru sprawiedliwości — jest wystarczający, aby był on skuteczny wobec obywateli oraz dawał im efektywną ochronę i możliwość dochodzenia swoich praw.

2 Ustawa zasadnicza Finlandii z 11 czerwca 1999 roku weszła w życie 1 marca 2000 roku. Najnowszego przekładu i analizy tekstu w jej aktualnym brzmieniu dokonała V. Serzhanova, Suomen perustuslaki. Ustawa zasadnicza Finlandii, Rzeszów 2017, s. 143-188.

${ }^{3}$ Finlandia należy do kręgu kultury prawnej świata nordyckiego i obok Szwecji zaliczana jest do tak zwanej kultury wschodnio-nordyckiej. Szerzej o tym zob. V. Serzhanova, op. cit., s. 7 n.; eadem, Ewolucja konstytucji państw nordyckich, [w:] Państwo i prawo w dobie globalizacji, red. S. Sagan, Rzeszów 2011, s. 270; por. również eadem, Tryb uchwalania oraz reforma Konstytucji Republiki Islandii, [w:] W kręgu zagadnień konstytucjonalizmu oraz wspótczesnego państwa, red. V. Serzhanova, Rzeszów 2015, s. 31 . O roli sądów w sprawowaniu wymiaru sprawiedliwości w państwach nordyckich, o wschodnio-nordyckiej tradycji powoływania sądów powszechnych i administracyjnych oraz o nordyckich systemach prawa materialnego i procesowego, w tym finlandzkim zob. eadem, Sąy w państwach nordyckich, [w:] Sądownictwo w Europie w XIX i XX wieku, red. E. Leniart, R. Świrgoń-Skok, W.P. Wlaźlak, Kraków 2016, s. 147-167; eadem, Sądownictwo najwyższe w państwach nordyckich. Zarys problematyki, „Roczniki Nauk Prawnych KUL” 2018, nr 2, s. 95-108, w języku angielskim: eadem, Supreme Court systems in the Nordic countries. An outline of the issue, „Roczniki Nauk Prawnych” 28, 2018, nr 2, s. 81-94. Por. M. Grzybowski, Finlandia. Zarys systemu ustrojowego, Kraków 2007, s. 131.

${ }^{4} \mathrm{Na}$ gruncie finlandzkiej konstytucji system sądownictwa tworzą przede wszystkim sądy powszechne i sądy administracyjne. Sądy powszechne obejmują sądy dwóch instancji: rejonowe i apelacyjne oraz — w najwyższej instancji — Sąd Najwyższy. Na sądy administracyjne składają się sądy administracyjne oraz Najwyższy Sąd Administracyjny. Ponadto ustawa zasadnicza powołuje sądy szczególne: Sąd Gospodarczy, Sąd Pracy, Sąd Ubezpieczeń i Sąd Stanu. Ze względu na ograniczenia co do objętości niniejszego opracowania nie sposób dokonać analizy całego systemu sądownictwa w Finlandii. Bez wątpienia taki wysiłek dałby najpełniejszy obraz jego ustroju i funkcjonowania oraz pozwoliłby na wysunięcie najbardziej wiarygodnych wniosków dotyczących skuteczności jego działania. Wymagałoby to jednak przygotowania co najmniej bardzo obszernego studium, a nawet mogłoby się stać przedmiotem monografii. Dokonanie tego nie jest zatem możliwe w ramach niewielkiego artykułu, zresztą nie to jest jego celem. Szerzej o ustroju sądów w Finlandii zob. I. Saraviita, The Constitution of Finland, Helsinki 2004, s. 195-196. 


\section{NACZELNE ZASADY KONSTYTUCJI FINLANDII DOTYCZACE WŁADZY SĄDOWNICZEJ I WYMIARU SPRAWIEDLIWOŚCI}

Jedno z najistotniejszych postanowień konstytucji Finlandii, bezpośrednio odnoszące się do wymiaru sprawiedliwości, z tym w szczególności do sądownictwa, to naczelna konstytucyjna zasada podziału władz, zawarta $\mathrm{w} \S 3$ ustawy zasadniczej, zgodnie z którą władzę sądowniczą w Finlandii realizują niezależne sądy, w tym Sąd Najwyższy oraz Najwyższy Sąd Administracyjny jako sądy najwyższych instancji. Tym samym do sprawowania wymiaru sprawiedliwości przepis ten powołuje system sądów oraz determinuje i gwarantuje status władzy sądowniczej jako niezależnej od innych władz, przede wszystkim od państwowych organów władzy ustawodawczej i wykonawczej. Zasada ta ma kapitalne znaczenie dla statusu sądów i sędziów w systemie wymiaru sprawiedliwości ${ }^{5}$.

Zasady legalizmu i niezawisłości sędziów są podstawą ustroju sądów w Finlandii. Z nich wypływa wiele innych reguł mających fundamentalne znaczenie dla całego wymiaru sprawiedliwości. Nie sposób zatem nie zgodzić się z Marianem Grzybowskim, który twierdzi, że

z zasad legalizmu oraz niezawisłości sędziów fińska doktryna ustrojowa wywiodła dalsze reguły funkcjonowania sądów: ich podporządkowania tylko ustawie, dwuinstancyjność orzekania, domniemania niewinności oskarżonego w procesie karnym, jawność postępowania sądowego oraz prawa do zaskarżania orzeczeń sądowych pierwszej instancji. Z czasem ukształtował się nadto postulat powierzenia wymiaru sprawiedliwości wyłącznie organom sądowym ${ }^{6}$.

W tym kontekście równie istotna wydaje się gwarancja ochrony prawnej, zawarta $\mathrm{w} \S 21$ ustawy zasadniczej. Zapewnia ona każdemu prawo do kierowania jego sprawy do rozpatrzenia przez właściwy sąd w sposób rzetelny i bez zbędnej zwłoki oraz do otrzymania orzeczenia sądu bądź innego niezależnego organu wymiaru sprawiedliwości zajmującego się jego prawami i obowiązkami. Wprowadza ponadto fundamentalne gwarancje procesowe, takie jak zasada jawności postępowania, prawo do składania zeznań, prawo do otrzymywania wyroku z uzasadnieniem oraz prawo do środka odwoławczego, jak również inne gwarancje uczciwego procesu oraz dobrej administracji, szczegółowo uregulowane w drodze ustaw.

5 Por. V. Serzhanova, Suomen..., s. 117 n.; również I. Saraviita, op. cit., s. 195. O naczelnych zasadach w konstytucji Finlandii bardziej szczegółowo zob. V. Serzhanova, Naczelne zasady ustroju politycznego w Konstytucji Republiki Finlandii, [w:] Zagadnienia prawa konstytucyjnego. Polskie i zagraniczne rozwiązania ustrojowe. Ksiegga jubileuszowa dedykowana Profesorowi Dariuszowi Góreckiemu w siedemdziesiąta rocznicę urodzin, red. K. Skotnicki, K. Składowski, A. Michalak, Łódź 2016, s. 363-377.

${ }^{6}$ M. Grzybowski, op. cit., s. 132. Por. M. Hidén, The Parliamentary Ombudsman in Finland. Position and Functions, Helsinki 1976, s. 10-11. 


\section{POSTANOWIENIA USTAWY ZASADNICZEJ DETERMINUJĄCE ZASADY ORGANIZACJI I DZIAŁANIA WYMIARU SPRAWIEDLIWOŚCI}

Samemu wymiarowi sprawiedliwości i systemowi sądownictwa sensu stricto ustawa zasadnicza Finlandii poświęca rozdział 9 Wymiar sprawiedliwości (§ 98105). Nie jest on szczególnie rozbudowany, a postanowienia w nim zawarte są raczej dosyć skąpe, gdyż tradycją państw nordyckich jest pozostawienie szczegółowych regulacji w tym zakresie drodze ustawowej, ustawa zasadnicza natomiast najczęściej zawiera jedynie postanowienia dotyczące powołania sądów jako organów wymiaru sprawiedliwości, określenia ich zadań, względnie ogólnej procedury powoływania sędziów oraz ich statusu, tym samym nadając rangę konstytucyjną tej materii. Nie inaczej jest w konstytucji Finlandii. Wobec stosownego rozwinięcia tych regulacji w drodze ustawy lakoniczność tych postanowień konstytucji jest naturalna, zrozumiała i w moim przekonaniu nie stanowi wady tego aktu? ${ }^{7}$.

Postanowienia konstytucji zawarte w rozdziale 9 tworzą sądy powszechne, do których zaliczają przede wszystkim Sąd Najwyższy, lecz również sądy apelacyjne oraz sądy rejonowe (§98). Nadto ustawa zasadnicza zakazuje powoływania sądów doraźnych. Do rozstrzygania konfliktów z zakresu prawa administracyjnego postanowienia rozdziału 9 konstytucji powołują Najwyższy Sąd Administracyjny oraz sądy administracyjne ${ }^{8}$. Szczegółowo materia sądownictwa powszechnego i administracyjnego stanowi przedmiot regulacji ustawowych ${ }^{9}$.

7 O sądach i organach ochrony porządku prawnego por. M. Grzybowski, op. cit., s. $131 \mathrm{n}$.

8 I. Saraviita, op. cit., s. 195-196.

9 Od 1 stycznia 2017 roku w Finlandii obowiązuje ustawa z dnia 25 sierpnia 2016 roku o sądach, nr 673/2016, która w miarę jednolicie uporządkowała regulację materii z zakresu sądownictwa powszechnego i administracyjnego. $Z$ tego samego dnia pochodzi wiele innych ustaw dotyczących działalności sędziów i sądów. Do tego czasu materia ta była unormowana jedynie fragmentarycznie, gdyż istniało wiele odrębnych aktów, na przykład: ustawa z dnia 22 lipca 1918 roku o Sądzie Najwyższym, nr 74/1918; ustawa z dnia 22 grudnia 2006 roku o Najwyższym Sądzie Administracyjnym, nr 1265/2006; ustawa z dnia 25 lutego 2000 roku o powoływaniu sędziów, nr 205/2000, a także o niektórych sądach szczególnych — gospodarczym, pracy i wiele innych. Stan aktów normatywnych w tej kwestii był zatem bardzo rozproszony i niezupełny. Obecnie stan ustawodawstwa w tym zakresie jest bardziej aktualny, zupełny i mniej rozproszony, choć w dalszym ciągu daje się zaobserwować pewien stopień rozdrobnienia i wielości ustaw odnoszących się do władzy sądowniczej i wymiaru sprawiedliwości. Wszystkie te oraz inne przywoływane w dalszych częściach opracowania akty dostępne są w językach fińskim i szwedzkim, a niektóre także w języku angielskim w elektronicznych zbiorach aktów prawnych Finlandii pod adresem internetowym http://www.finlex.fi (dostęp: 7.08.2020). Problematykę ustroju sądów analizuje S. Sarvilinna, Court administration in Finland, „Scandinavian Studies in Law” 2007, nr 51, s. 591-605; w literaturze polskiej por. V. Serzhanova, Współczesny system sądownictwa w Finlandii, „Gubernaculum et Administratio. Historia, Prawo, Administracja. Zeszyty Naukowe Instytutu Administracji Wyższej Szkoły Pedagogicznej w Częstochowie" 2002, z. 2, s. 121-128. 
Ustawa zasadnicza powołuje Sąd Najwyższy jako najwyższą instancję sądową w sprawach cywilnych, gospodarczych i karnych, w sprawach administracyjnych zaś konstytucja w tym celu powołuje Najwyższy Sąd Administracyjny. Zgodnie z jej § 99 do kompetencji Sądu Najwyższego i Najwyższego Sądu Administracyjnego należy sprawowanie nadzoru nad wymiarem sprawiedliwości w zakresie swojej właściwości. Może on również kierować do Rady Państwa (rządu) propozycje dotyczące zainicjowania nowych aktów ustawodawczych ${ }^{10}$.

Konstytucja w $§ 100$ dość ogólnikowo określa organizację Sądu Najwyższego i Najwyższego Sądu Administracyjnego, stanowiąc, że składają się one z prezesa oraz wymaganej liczby sędziów. Dokładnie jednakże nie określa tej liczby. Determinuje za to składy orzekające uprawnione do rozstrzygania spraw w liczbie pięciu sędziów, chyba że inny skład zostanie ustalony w drodze ustawy.

Niezwykle ważne jest konstytucyjne określenie procedury powoływania sędziów. Została ona zawarta w $§ 102$ ustawy zasadniczej. Mimo że uregulowana jest dosyć ogólnie i lakonicznie, nadaje urzędowi sędziego odpowiednią rangę oraz stabilizuje i utrwala jego niezależny i niezawisły status. Postanowienie konstytucji stanowi, że sędziów na czas nieoznaczony powołuje prezydent Republiki ${ }^{11}$.

Natomiast przepis $\S 103$ zawiera równie istotne postanowienie stanowiące dodatkową gwarancję urzeczywistnienia niezależnego statusu sędziów. Norma ta wyposaża sędziów w atrybuty nieusuwalności i nieprzenaszalności polegające w szczególności na tym, że sędzia nie może zostać pozbawiony stanowiska, chyba że na podstawie wyroku sądowego, oraz nie może zostać przeniesiony na inne stanowisko bez jego zgody, z wyjątkiem sytuacji przeniesienia na skutek reorganizacji sądownictwa. Postanowienie to również przewiduje obowiązek sędziego do złożenia rezygnacji po osiągnięciu określonego wieku lub z powodu utraty zdolności do wykonywania zawodu, które to sprawy są również szczegółowo uregulowane ustawowo, podobnie jak inne warunki wykonywania zawodu sędziego.

Należy podkreślić, że w ustawie zasadniczej Finlandii próżno szukać postanowień gwarantujących sędziom immunitet w zakresie pociągnięcia ich do odpo-

10 Szerzej zob. V. Serzhanova, Sądownictwo najwyższe..., s. 95-108. Dogłębnie problematykę roli i pozycji, a także zadań sądownictwa najwyższego w państwach nordyckich, w tym w Finlandii, bada P.H. Lindblom, The role of the Supreme Courts in Scandinavia, „Scandinavian Studies in Law” 2000, nr 39, s. 332 n. Por. D. Tamm, Nordic Supreme Courts - differences and similarities, [w:] Rule of Law - Development and Judicial Reform, Beijing 2016, s. 112-120; także idem, Nordic unity and Nordic Supreme Courts: Differences and similarities, [w:] Unity and Plurality in the Legal History of the Baltic Sea Area, red. M. Luts-Sootak, S. Osipova, F.L. Schäfer, Wien 2012, s. 287-294.

11 Szczegółowo tryb powoływania sędziów został unormowany w odrębnej, przywołanej już, ustawie z dnia 25 lutego 2000 roku o powoływaniu sędziów, nr 205/2000, obowiązującej od 1 marca 2000 roku. 
wiedzialności prawnej. Co więcej, postanowienia konstytucji w § 110 przewidują taką możliwość, uprawnienia w tym zakresie mają zaś Kanclerz Sprawiedliwości Rady Państwa oraz Ombudsman Eduskunty.

System sądów powszechnych w Finlandii obejmuje sądy dwóch instancji — sądy rejonowe (fiń. käräjäoikeus, szw. tingsrätt ${ }^{12}$ ) i sądy apelacyjne (fiń. hovioikeus, szw. hovrätt) oraz - w najwyższej instancji - Sąd Najwyższy (fiń. korkein oikeus - KKO, szw. högsta domstolen - HD) z siedzibą w Helsinkach. W kompetencji sądów powszechnych, poza sprawami z zakresu prawa karnego, cywilnego i gospodarczego, znajduje się także wojskowy wymiar sprawiedliwości. W systemie sądów administracyjnych są powołane i działają sądy administracyjne (fiń. hallinto-oikeus, szw. förvaltningsdomstol) oraz — jako najwyższa instancja - Najwyższy Sąd Administracyjny (fiń. korkein hallinto-oikeus, szw. högsta förvaltningsdomstolen). Do sądów szczególnych natomiast zalicza się: Sąd Gospodarczy (fiń. markkinaoikeudessa, szw. marknadsdomstolen) ${ }^{13}$, Sąd Pracy (fiń. työtuomioistuimessa, szw. arbetsdomstolen), Sąd Ubezpieczeń (fiń. vakuutusoikeudessa, szw. försäkringsdomstolen) i Sąd Stanu (fin. Valtakunnanoikeus, szw. Riksrätten ${ }^{14}$. Wszystkie sądy szczególne mają swoje siedziby w Helsinkach.

Sądy realizują zadania powierzone im na mocy ustawy zasadniczej w sposób niezależny i niezawisły. Oznacza to, że nikt z zewnątrz nie może ingerować ani wpływać na treść podejmowanych przez sądy decyzji oraz że w pełnieniu swoich obowiązków sędziowie są związani jedynie prawem i orzekają na podstawie obowiązujących przepisów. Szczegółowe regulacje dotyczące gwarancji niezależności sądów i wszelkich przynależnych jej atrybutów znajdują się w przywołanej wcześniej ustawie o sądach z 2016 roku ${ }^{15}$.

12 Termin ting ma bardzo głęboko sięgającą tradycję w Skandynawii, kiedy to wolni mężczyźni z danego okręgu spotykali się, aby decydować o sprawach publicznych. Owe zebrania ludowe, na których stanowiono prawo, rozstrzygano sprawy publiczne oraz rozsądzano spory, były ośrodkiem takich decyzji. Prawo głosowania i udziału w rozstrzyganiu mieli wolni włościanie. Zgromadzeniom tym przewodniczył obdarzony zaufaniem publicznym lagman (człowiek prawa), jeden z zamożniejszych, jednak niemający określonej stałej władzy. Zapadające decyzje były wytworem pewnych kolektywnych rozwiązań, wyrazem woli ogółu, a nie jednostki lub nielicznej grupy rządzącej i co bardzo istotne - zebrania ludowe były miejscem wykonywania władzy sądowej. Szerzej zob. K. Ciemniewski, Zasady ustroju politycznego Finlandii, Bydgoszcz 1971, s. 10; także N. Herlitz, Elements of Nordic Public Law, Stockholm 1969, s. 171 n. Obszerniej instytucję tingów wyjaśnia L. Leciejewicz, Normanowie, Wodzisław Śląski 1979, s. 94; oraz A.S. Kan, Istorija skandinavskich stran (Danija, Szvecyja, Norvegija), Moskva 1980, s. 21 n.

13 W dosłownym thumaczeniu „sąd rynku”.

14 I. Saraviita, op. cit., s. 199.

15 Ibidem, s. 198. 


\section{KOMPETENCJE SĄDÓW W ZAKRESIE KONTROLI KONSTYTUCYJNOŚCI PRAWA}

W Finlandii, jak zresztą w żadnym państwie nordyckim ${ }^{16}$, nie istnieje system scentralizowanej kontroli konstytucyjności prawa oparty na kelsenowskim modelu sądownictwa konstytucyjnego, który upowszechnił się w wielu krajach Europy i świata ${ }^{17}$. W pewnym stopniu kontrolę konstytucyjności prawa w postaci oceny zgodności przepisów aktów niższego rzędu z ustawą zasadniczą prowadzą między innymi sądy powszechne przy okazji rozstrzygania konkretnych spraw.

Formalnoprawnie takie uprawnienie sądów do realizowania rozproszonej kontroli konstytucyjności prawa zostało usankcjonowane w $§ 106$ i 107 ustawy zasadniczej, zawartych w rozdziale 10 Nadzór nad praworząnościa. Paragraf 106 stanowi o uprawnieniu sądu do uznania nadrzędności postanowień konstytucji w sytuacji, gdyby podczas rozpoznawania sprawy zastosowanie przepisu ustawy znalazło się w ewidentnej sprzeczności z konstytucją. W podobnym duchu, odnosząc się do aktów podustawowych, wypowiada się § 107, zezwalając sądom na niestosowanie przepisu dekretu lub innego aktu niższego rzędu niż ustawa, jeżeli

16 Zob. K.M. Bruzelius, The Nordic Constitutions and Judicial Review, http://www.constcourt.md/public/files/file/conferinta_20ani/programul_conferintei/Karin_Bruzelius_2.pdf (dostęp: 7.08.2020); A. Follesdal, M. Wind, Introduction - Nordic reluctance towards judicial review under siege, „Nordisk Tidsskrift for Menneskerettigheter” 27, 2009, nr 2, s. 131-141; A. Bårdsen, The Nordic Supreme Courts as Constitutional Courts: Main Features as Seen from the Norwegian Perspective, Joint Seminar between the Constitutional Court of Austria and the Supreme Court of Norway, Vienna the 29-30th of October 2015, https://www.domstol.no/globalassets/upload/ hret/artikler-og-foredrag/nordic-constitutional-courts---vienna-29102015.pdf (dostęp: 7.08.2020); L. Garlicki, Constitutional Courts versus Supreme Courts, „International Journal of Constitutional Law" 5, 2007, nr 1, s. 44-68; R. Helgadóttir, Nonproblematic judicial review: A case study, „International Journal of Constitutional Law” 9, 2011, nr 2, s. 532-547; R. Hirschl, The Nordic counternarrative: Democracy, human development and judicial review, „International Journal of Constitutional Law" 9, 2011, nr 2, s. 449-469.

17 Wynika to z jednej strony z pewnej mocno zakorzenionej i utrwalonej tradycji charakterystycznej dla państw świata nordyckiego, które wypracowały własne, oryginalne mechanizmy oparte głównie na kontroli wewnątrz parlamentarnej, zapewniające odpowiedni i wystarczający poziom ochrony konstytucji. Z drugiej zaś strony w obszarze praktyki stosowania przepisów prawa wykonywanie takiej kontroli powierzono sądom powszechnym i administracyjnym. W istocie rzeczy w Finlandii kładzie się nacisk raczej na kontrolę prewencyjną wiążącą się ściśle z procedurą uchwalania ustaw. Interesujący dyskurs o wewnątrzparlamentarnej kontroli konstytucyjności prawa można znaleźć w R. Piotrowski, Parlamentarna kontrola konstytucyjności aktów prawnych, [w:] Prawo i kontrola jego zgodności z konstytucją, red. E. Zwierzchowski, Warszawa 1997, s. 108 n. Szerzej o kontroli konstytucyjności prawa w Finlandii zob. V. Serzhanova, Kontrola konstytucyjności prawa w Finlandii, [w:] Aktualne problemy konstytucji. Księga Jubileuszowa z okazji 40-lecia pracy naukowej Profesora Bogustawa Banaszaka, red. H. Babiuch, P. Kapusta, J. Michalska, Legnica 2017, s. 802-816. Por. V. Serzhanova, S. Sagan, Kontrola konstytucyjności prawa w państwach nordyckich, [w:] Prawo w stużbie państwu i spoleczeństwu. Prace dedykowane Profesorowi Kazimierzowi Działosze z okazji osiemdziesiatych urodzin, red. B. Banaszak, M. Jabłoński, S. Jarosz-Żukowska, Wrocław 2012, s. 185. 
stoi on w sprzeczności z konstytucją lub ustawą. Sądy administracyjne badają zarówno zgodność aktu administracyjnego z ustawą zasadniczą, jak i zgodność z konstytucją ustawy, na której podstawie go wydano ${ }^{18}$.

Naturalną konsekwencją tych postanowień konstytucji w praktyce wydaje się to, że sądy mają możliwość dokonywania oceny konstytucyjności aktów niższego rzędu oraz - w razie stwierdzenia takiej sprzeczności — ich niezastosowania w konkretnej sprawie. Wydaje się też, iż ujęcie § 106 obejmującego w swojej treści pojęcie zgodności ustaw z ,ustawą zasadniczą" (fiń. perustuslain kanssa), a nie tylko z jej poszczególnymi postanowieniami, może implikować również, że sądy mogą dokonywać szerokiej wykładni ustawy zasadniczej, sięgając także do jej „ducha” i wartości w niej zawartych ${ }^{19}$. Identyczny skutek sądy mogą osiągnąć też poprzez wykładnię (albo tworzenie) przepisu lub zasady prawnej w sposób „prokonstytucyjny” lub ,przyjazny prawom człowieka”.

Nie oznacza to bynajmniej, że sąd jest wyposażony w kompetencje lub jakiekolwiek instrumenty prawne umożliwiające mu orzekanie o niezgodności takiego przepisu lub aktu normatywnego w sensie powszechnie obowiązującym i że na tej podstawie przepis uznany za niekonstytucyjny w danej sprawie może nie być stosowany przez inne sądy. Działalność sądów powszechnych i administracyjnych w tym zakresie nie wywołuje zatem takich samych skutków prawnych jak wyroki sądów konstytucyjnych, gdyż nie mają one charakteru abstrakcyjnego i powszechnie obowiązującego.

Ponadto warto przypomnieć, że Sąd Najwyższy i Najwyższy Sąd Administracyjny mogą dokonywać prewencyjnej kontroli rządowych inicjatyw ustawodawczych na różnych etapach postępowania toczącego się w parlamencie. Przewodniczący Eduskunty może zwrócić się o zaopiniowanie uchwalonej ustawy, czyni to jednakże przed jej podpisaniem przez prezydenta ${ }^{20}$.

\section{KONKLUZJE}

Jak wynika z analizy omówionych postanowień, ustawa zasadnicza Finlandii powołuje system sądów powszechnych i administracyjnych jako dwa odrębne piony organów sprawujących wymiar sprawiedliwości oraz nadaje im szczególny

18 Por. V. Serzhanova, Kontrola ..., s. 802-816; V. Serzhanova, S. Sagan, Kontrola ..., s. 185.

19 O interpretacji § 106 konstytucji finlandzkiej, jak również szerzej o sądowej kontroli konstytucyjności prawa w państwach nordyckich, w tym w Finlandii, zob. V. Serzhanova, Kontrola..., s. 802-816; por. V. Serzhanova, S. Sagan, Kontrola..., s. 185.

${ }^{20}$ Najwyższy Sąd Administracyjny jeszcze w 1919 roku został wyposażony w prawo wyrażania opinii o projektach ustaw przedkładanych Eduskuncie. Warto w tym kontekście sięgnąć do komentarza zawartego w opracowaniu M. Grzybowskiego, Państwa nordyckie (szwedzkie i fińskiej sądownictwo administracyjne), [w:] Sadownictwo administracyjne w Europie Zachodniej, red. L. Garlicki, Warszawa 1990, s. 203. Por. V. Serzhanova, S. Sagan, Kontrola ..., s. 185. 
status. Postępowanie przed sądami musi być rzetelne, a same sądy działają jako organy obiektywne $\mathrm{i}$ bezstronne, podejmujące rozstrzygnięcia $\mathrm{w}$ miarę jednolite w podobnych sprawach. W swoich orzeczeniach są niezależne i nie podlegają kontroli państwa w zakresie judykacyjnym. Wyroki sądowe stanowią ostateczny środek gwarantujący stronom przestrzeganie ich praw w relacjach z państwem. Są one podstawowym mechanizmem rozstrzygania sporów wynikających ze stosunków prawnych, a także ochrony praw i wolności oraz samej ustawy zasadniczej.

Wnikliwa analiza zarówno warstwy konstytucyjnej, jak i całych dziejów państwa przez wieki skłania do refleksji, że w swojej tradycji historycznej Finlandia, w tym społeczeństwo fińskie, zawsze była i pozostaje państwem o wysokim poczuciu legalizmu i patosu konstytucyjnego. Szczególne ważne miejsce w tym kontekście zajmuje materia wartości i zasad konstytucyjnych, a także podstawowych praw i wolności człowieka i obywatela, zagwarantowanych w ustawie zasadniczej. Wysoki poziom ich przestrzegania w Finlandii wynika nie tylko z pewnej utrwalonej w tym zakresie tradycji historycznej, mocno zakotwiczonej w mentalności i głęboko zakorzenionej w świadomości narodowej Finów, lecz także ze skutecznie skonstruowanych przez państwo instrumentów prawnych ich ochrony.

Pokojowa ewolucja ustroju Finlandii, odbywająca się w spokojny, rozważny i rozciągnięty w czasie sposób, bez większych wstrząsów i jakichkolwiek rewolucyjnych zmian, skutkowała niezwykle dojrzałym podejściem osób piastujących najwyższe stanowiska państwowe i sprawujących władzę w tych państwach do konstytucji jako wartości nadrzędnej, pojmowania racji stanu tych państw i traktowania państwa jako dobra wspólnego wszystkich obywateli. Wśród szczególnie pielęgnowanych przez Finlandię tradycji można by uplasować przede wszystkim naczelne zasady ustroju politycznego zawarte w konstytucji, mocno utrwalone we współczesnych mechanizmach systemu politycznego, zwłaszcza odnoszące się do niezależności sądów i niezawisłości sędziów, a także ścisłe przestrzeganie praw i wolności jednostki zwłaszcza w kontekście ich relacji z władzą publiczną. Stanowi to swoistą właściwość i zarazem osobliwość państw nordyckich, również Finlandii, od wieków bowiem kwestia statusu jednostki i ochrona jej praw była i wciąż pozostaje niezwykle istotnym obszarem funkcjonowania tych państw.

\section{CONSTITUTIONAL FOUNDATIONS OF THE ORGANISATION AND FUNCTIONING OF THE JUDICIARY IN FINLAND}

\section{Summary}

Nowadays, the autonomy of courts and independence of judges are the fundamental attributes of justice in a democratic legal state. On the grounds of the constitutional system of Finland, the Basic Law of 1999 creates a dualistic judicial system of common and administrative courts. The purpose of this study is to subject the provisions of the Finnish Basic Law creating the constitutional basis of the organisation and functioning of the common judiciary in Finland to legal analysis, which 
allows us to make a conclusion, that courts act as objective and impartial bodies, making decisions relatively uniform in similar cases. In their rulings they are independent and are not subject to state control in the field of the judiciary. Court judgments are the final measure guaranteeing the parties' respect of their rights in relations with the state.

Keywords: independent courts and judges, the Constitution of Finland 1999

\section{BIBLIOGRAFIA}

Ambrasaitė-Balynienè G., Comparative Analysis on the High Councils for Judiciary in the EU Member States and Judicial Immunity, European Commission / ENPI, październik 2015.

Bårdsen A., The Nordic Supreme Courts as Constitutional Courts: Main Features as Seen from the Norwegian Perspective, Joint Seminar between the Constitutional Court of Austria and the Supreme Court of Norway, Vienna the 29-30th of October 2015, https://www.domstol.no/globalassets/upload/hret/artikler-og-foredrag/nordic-constitutional-courts---vienna-29102015. pdf.

Bruzelius K.M., The Nordic Constitutions and Judicial Review, http://www.constcourt.md/public/ files/file/conferinta_20ani/programul_conferintei/Karin_Bruzelius_2.pdf.

Ciemniewski K., Zasady ustroju politycznego Finlandii, Bydgoszcz 1971.

Follesdal A., Wind M., Introduction - Nordic reluctance towards judicial review under siege, „Nordisk Tidsskrift for Menneskerettigheter"27, 2009, nr 2.

Garlicki L., Constitutional Courts versus Supreme Courts, „International Journal of Constitutional Law" 5, 2007, $\mathrm{nr} 1$.

Grzybowski M., Finlandia. Zarys systemu ustrojowego, Kraków 2007.

Grzybowski M., Państwa nordyckie (szwedzkie i fińskiej sądownictwo administracyjne), [w:] Sadownictwo administracyjne w Europie Zachodniej, red. L. Garlicki, Warszawa 1990.

Helgadóttir R., Nonproblematic judicial review: A case study, „International Journal of Constitutional Law" 9, 2011, nr 2.

Herlitz N., Elements of Nordic Public Law, Stockholm 1969.

Hidén M., The Parliamentary Ombudsman in Finland. Position and Functions, Helsinki 1976.

Hirschl R., The Nordic counternarrative: Democracy, human development and judicial review, „International Journal of Constitutional Law" 9, 2011, nr 2.

Kan A.S., Istorija skandinavskich stran (Danija, Szvecyja, Norvegija), Moskva 1980.

Leciejewicz L., Normanowie, Wodzisław Śląski 1979.

Lindblom P.H., The role of the Supreme Courts in Scandinavia, „Scandinavian Studies in Law" 2000, nr 39.

Piotrowski R., Parlamentarna kontrola konstytucyjności aktów prawnych, [w:] Prawo i kontrola jego zgodności z konstytucja, red. E. Zwierzchowski, Warszawa 1997.

Saraviita I., The Constitution of Finland, Helsinki 2004.

Sarvilinna S., Court administration in Finland, „Scandinavian Studies in Law” 2007, nr 51.

Serzhanova V., Ewolucja konstytucji państw nordyckich, [w:] Państwo i prawo w dobie globalizacji, red. S. Sagan, Rzeszów 2011.

Serzhanova V., Kontrola konstytucyjności prawa w Finlandii, [w:] Aktualne problemy konstytucji. Księga Jubileuszowa z okazji 40-lecia pracy naukowej Profesora Bogusława Banaszaka, red. H. Babiuch, P. Kapusta, J. Michalska, Legnica 2017.

Serzhanova V., Naczelne zasady ustroju politycznego w Konstytucji Republiki Finlandii, [w:] Zagadnienia prawa konstytucyjnego. Polskie i zagraniczne rozwiąania ustrojowe. Ksiega jubi- 
leuszowa dedykowana Profesorowi Dariuszowi Góreckiemu w siedemdziesiąta rocznicę urodzin, red. K. Skotnicki, K. Składowski, A. Michalak, Łódź 2016.

Serzhanova V., Sąownictwo najwyższe w państwach nordyckich. Zarys problematyki, „Roczniki Nauk Prawnych KUL”2018, nr 2.

Serzhanova V., Sądy w państwach nordyckich, [w:] Sadownictwo w Europie w XIX i XX wieku, red. E. Leniart, R. Świrgoń-Skok, W.P. Wlaźlak, Kraków 2016.

Serzhanova V., Supreme Court systems in the Nordic countries. An outline of the issue, „Roczniki Nauk Prawnych" 28, 2018, nr 2.

Serzhanova V., Tryb uchwalania oraz reforma Konstytucji Republiki Islandii, [w:] W kręu zagadnień konstytucjonalizmu oraz współczesnego państwa, red. V. Serzhanova, Rzeszów 2015.

Serzhanova V., Współczesny system sądownictwa w Finlandii, „Gubernaculum et Administratio. Historia, Prawo, Administracja. Zeszyty Naukowe Instytutu Administracji Wyższej Szkoły Pedagogicznej w Częstochowie "2002, z. 2.

Serzhanova V., Sagan S., Kontrola konstytucyjności prawa w państwach nordyckich, [w:] Prawo w stużbie państwu i społeczeństwu. Prace dedykowane Profesorowi Kazimierzowi Działosze z okazji osiemdziesiatych urodzin, red. B. Banaszak, M. Jabłoński, S. Jarosz-Żukowska, Wrocław 2012.

Tamm D., Nordic Supreme Courts - differences and similarities, [w:] Rule of Law - Development and Judicial Reform, Beijing 2016.

Tamm D., Nordic unity and Nordic Supreme Courts: Differences and similarities, [w:] Unity and Plurality in the Legal History of the Baltic Sea Area, red. M. Luts-Sootak, S. Osipova, F.L. Schäfer, Wien 2012.

\section{AKTY NORMATYWNE}

Ustawa zasadnicza Finlandii z 11 czerwca 1999 roku, [w:] V. Serzhanova, Suomen perustuslaki. Ustawa zasadnicza Finlandii, Rzeszów 2017.

Ustawa z dnia 22 lipca 1918 roku o Sądzie Najwyższym, nr 74/1918.

Ustawa z dnia 25 lutego 2000 roku o powoływaniu sędziów, nr 205/2000.

Ustawa z dnia 22 grudnia 2006 roku o Najwyższym Sądzie Administracyjnym, nr 1265/2006.

Ustawa z dnia 25 sierpnia 2016 roku o sądach, nr 673/2016. 